$11-2-2009$

\title{
Evidence Issues In CINA Cases
}

Lynn McLain

University of Baltimore, lmclain@ubalt.edu

Follow this and additional works at: http://scholarworks.law.ubalt.edu/all_fac

Part of the Family Law Commons, and the Legal Education Commons

\section{Recommended Citation}

Lynn McLain, Evidence Issues In CINA Cases, (2009).

Available at: http://scholarworks.law.ubalt.edu/all_fac/917

This Article is brought to you for free and open access by the Faculty Scholarship at ScholarWorks@University of Baltimore School of Law. It has been accepted for inclusion in All Faculty Scholarship by an authorized administrator of ScholarWorks@University of Baltimore School of Law. For more information, please contact snolan@ubalt.edu. 


\section{EVIDENCE ISSUES IN CINA CASES}

November 2, 2009

Lynn McLain

University of Baltimore School of Law

I. Do the Rules of Evidence (Including the Hearsay Rule) Apply? ${ }^{1}$

A. Yes, in:

- Juvenile adjudicatory hearings, generally, In re Michael G., 107 Md. App. 257, 265, 667 A.2d 956 (1995).

B. No (except Testimonial Privileges ${ }^{2}$ which do apply), in:

- Detention and shelter care hearings under Rule 11-112 (Md. Rules 5-101(b)(11) \& 11-112d).

C. Rules re: Testimonial Privileges ${ }^{3}$ and Competency of Witnesses ${ }^{4}$ Apply, But the Court, in the Interest of Justice, May Decline to Strictly Apply Other Evidence Rules, in:

- Disposition hearings under Md. Rule 11-115, including permanency planning hearings under Md. Code Ann., Cts. \& Jud. Proc. § 3-823 (Md. Rule 5-101(c)(6)); In re Ashley E., 387 Md. 260, 280-81, 874 A.2d 998 (2005).

- Modification hearings under Md. Rule 11-116 (Md. Rule 5-101(c)(7)).

D. Are There Standards Even If the Evidence Rules Do Not Apply?

- Yes, due process requires that the trial court evaluate "whether evidence proffered for admission is sufficiently reliable and

\footnotetext{
${ }^{1}$ See generally 5 Lynn MCLain, Maryland Evidence: State AND Federal § 101:1 (2d ed. 2001 \& Supp. 2007) (accessible on Westlaw as 5 Maryland Evidence $§ 101: 1$ ) (hereinafter "MARYLAND EVIDENCE").

2 As to testimonial privileges, see 6 MARYLAND EVIDENCE§§ 501:1-520:1 (2d ed. 2001 \& Supp. 2009) (available on Westlaw as [volume \#] Maryland Evidence [section \#]).

${ }^{3} I d$.

${ }^{4}$ See Md. Rules 5-601 \& 5-603; Matoumba v. State, 390 Md. 554, 553, 890 A.2d 288 (2006).
} 
probative...." In re Billy W., 387 Md. 405, 434, 875 A.2d 734 (2005)

(under facts of case, no error in admitting testimony of (1) a DSS social worker, to mother's statements during visits with the children, and to information provided social worker by psychologist conducting family therapy sessions, and (2) two CASA's, to statements made by the children and by one of their foster parents - CASA's should have been sworn and subject to cross-examination, but no objection was made on those bases).

\section{Parents' Opportunity to Testify and to Cross-Examine in Shelter Care Hearings}

- In re Damien F., 182 Md. App. 546, 958 A.2d 402 (2008) (reversing shelter case orders based on proffers from DSS and Department of Health and Mental Hygiene, when parents were denied opportunity to present witness testimony to challenge material allegations in Departments' CINA petitions; given contradiction of competing proffers, trial court should have exercised discretion, as parents also should have been afforded opportunity to cross-examine the Departments' witnesses; Court of Special Appeals also suggests lower court erred in crediting unnamed reporters, when it was given no information from which it could determine their credibility. The Court of Special Appeals held, at 583-85:

When presented with a request by counsel for the parent or parents to be allowed to present witnesses at a shelter care hearing, as a threshold matter, the court should ask counsel to denote the allegations asserted to be in dispute. The judge should make an initial determination as to whether the competing versions of behavior or events, viz a viz, the proffered testimony versus the allegations in the petition, are in dispute.

We hold that, unless the disputed allegation is probatively inconsequential to a determination of whether placement is required to protect a child from serious immediate danger or that removal from the home is necessary to provide for the safety and welfare of the child, the court must receive testimony as to the material, disputed allegations and a denial of the request to produce witnesses, in that instance, is an abuse of discretion.

$$
* * *
$$

... To be sure, the court, in any proceeding, may insist on the relevancy of the proposed testimony of a witness. The only limitation that the court should impose in a shelter care 
hearing is that only testimony of witnesses which directly contradicts the allegation of abuse may be offered.

(Emphasis in original; footnote omitted).

Note: Adverse inference when parent does not testify:

In re Damien F., $182 \mathrm{Md}$. App. at 584 n.5 ("We note in passing that the one witness who usually has peculiar knowledge of the facts underlying the disputed allegations is the parent who requests an evidentiary hearing in the shelter care proceeding. When such parent, after requesting an evidentiary hearing, then fails to take the witness stand and testify, the trial court may infer that the testimony not produced would have been unfavorable.").

\section{Testimonial Privileges v. Confidential Matters}

A. Attorney-Client Privilege

The Court of Appeals has found reversible error in a trial court's permitting a party to be asked on cross-examination whether he had talked about his testimony with his lawyer: the mere fact that confidential communications occurred, as well as when, is privileged. Blanks v. State, 406 Md. 526, 959 A.2d 1180 (2008) (defendant did not "open the door" on direct by testifying that he had told "just his father" about a particular fact).

See generally 6 MARYLAND EVIDENCE $§ \S 503: 1$ et seq.

B. Psychotherapist-Patient Privilege

See generally 6 MARYLAND EVIDENCE $§ \S 504: 1$ et seq.

1. In General

Md. Code Ann., Cts. \& Jud. Proc. § 9-109 protects "communications relating to diagnosis or treatment" of a patient's "mental or emotional disorder" from "a psychiatrist, licensed psychologist, or any other person participating directly or vitally with either in rendering those services in consultation with or under direct supervision of a psychiatrist or psychologist."

The statute does not protect statements made to psychotherapists for purposes other than treatment, such as for a court-ordered evaluation.

The Court of Special Appeals has indicated that the privilege does not extend to communications made by members of a group program, during therapy in group sessions (but they are "confidential records," which are entitled to some protection; see III.C. infra). Reynolds v. State, 98 Md. App. 348, 368, 633 A.2d 455 (1993) ("Records of statements made by the patient during group therapy sessions, records of statements made by the patient to other 
patients during a hospital stay, and records of medication prescribed for the patient are not privileged under C.J. §9-109. These records are confidential and the patient has a right to privacy with respect to them, but they should not be kept from defense counsel under the theory that they are privileged.") (dictum) (emphasis added).

\section{Waiver}

Under the statute, a minor child, or anyone under disability, is considered incompetent to assert or waive the privilege. In a child custody case, the child's parents may not assert or waive the child's privilege; the court must appoint a guardian to act in the child's best interest. Nagle v. Hooks, $296 \mathrm{Md}$. 123, 126, 460 A.2d 49 (1983). The same reasoning applies in a CINA proceeding.

The Court of Special Appeals has held that, in a CINA proceeding, a mother, who responded to the county department of social services' assertion that she was mentally unfit by submitting a doctor's letter concerning her recent mental evaluations, did not introduce her mental condition as an element of her claim or defense, and thus did not waive her psychotherapist-patient privilege. In re Matthew R., 113 Md. App. 701, 688 A.2d 955 (1997).

See generally 6 MARYLAND EVIDENCE $§ \S 504: 1-504: 3$.

\section{Exceptions in Similar Statutes}

Maryland also has similar statutes protecting the relationship of a client and a psychiatric-mental health nursing specialist, or a certified professional counselor ( 9-109.1), which tracks the psychiatrist-psychologist statute, except that $\S 9-109.1$ omits the exception found in $\S 9-109(\mathrm{~d})(5)$ regarding defective delinquency proceedings and instead adds the following subsection:

There is no privilege in:

(1) Any administrative or judicial nondelinquent juvenile proceeding;

(2) Any guardianship and adoption proceeding initiated by a child placement agency;

(3) Any guardianship and protective services proceeding concerning a disabled person; or

(4) Any criminal or delinquency proceeding in which there is a charge of child abuse or neglect or that arises out of an investigation of suspected child abuse or neglect. 


\section{4. $\quad$ Required Reporting of Child Abuse}

By virtue of Md. Code Ann., Fam. Law § 5-704, health practitioners and social workers who, during treatment, come across evidence of child abuse, must report that abuse, "notwithstanding ... any law on privileged communications." This requirement to report information outside the context of testifying as a witness in a court proceeding does not compromise the evidentiary testimonial privilege not to be compelled to testify in court.

\section{Confidential (But Not Privileged) Information}

See generally 6 MARYLAND EVIDENCE § 501:1.

\section{In Camera Review May Be Possible, Or It May Not Be Enough}

In Pennsylvania v. Ritchie, 480 U.S. 39 (1987), the United States Supreme Court held that, although a person accused of a sex crime against a child has no constitutional right to inspect confidential files of a child welfare agency that reflect the victim's statements regarding abuse, the trial court must review the files in camera to determine whether information is "material" to the defense.

In Zaal v. State, 326 Md. 54, 88, 602 A.2d 1247 (1992), the Court of Appeals reviewed a trial court's decision to deny a child abuse defendant access to the alleged victim's confidential school records. The defendant had subpoenaed the records from the School Board. After an in camera review, the trial court had concluded that it did not find " 'any kind of evidence that would be directly admissible for impeachment purposes.' " $I d$. The Court of Appeals reversed.

In an opinion by Judge Bell, the court first concluded that the federal statute underlying the applicable Maryland regulation did not "create a privilege against disclosure of student records to be invoked by the school, the student, or his or her parents." Id. Nonetheless, a student has a privacy interest in the records. Therefore, the trial judge, "in the exercise of discretion, must conduct a balancing test in which the privacy interest of the student is weighed against the genuine need of the party requesting the information for its disclosure." Id. at 73 .

The Court of Appeals found the goal of confidentiality under the student records statute to be (1) less important than that goal is with regard to a state's confidential child abuse information, such as that addressed by the United States Supreme Court in Pennsylvania v. Ritchie, and (2) weaker than the privacy interest protected by a similar Maryland child abuse records statute in State v. Runge, 317 Md. 613, 566 A.2d 88 (1989).

It pointed out that there are several alternative procedures for a trial court to consider:

(1) in camera review by the court alone, as was approved in Pennsylvania v. Ritchie;

(2) unqualified access by the defendant and defense counsel, as in Carr and 
Leonard with regard to prior written statements - as to which there is no privacy interest - of state's witnesses who have testified;

(4) review by counsel for both parties as officers of the court, followed by an in camera hearing on the admissibility of those portions of the records defense counsel seeks to admit.

Id. at 84-88. As guidance for trial courts in future cases, Judge Bell opined:

Which option the court chooses must depend on various factors, including the degree of sensitivity of the material to be inspected; the strength of the showing of the "need to inspect"; whether the information sought is readily identifiable; considerations of judicial economy, etc. The greater the "need to inspect" showing, i.e., as here, where it is self-evident [because the question of the victim's credibility is crucial to the case] and the less sensitive the information, for example, the more likely the records will be reviewed jointly by the court and counsel or by counsel as officers of the court. ...

Only when the records are not even arguably relevant and usable should the court deny the defendant total access to the records. In other words, except as to information, which, without regard to the perspective of the person conducting the review, has absolutely no possible relevance to the case, the trial court's in camera review should not be conducted with preclusive intent.

Id. at $87-88$.

When the trial court concludes that there is not even arguable relevance, it "should mark and seal the records excluded so that the judge's determination in that regard may be reviewed on appeal." $I d$. at 88 n.15. The Court of Appeals subsequently approved the same general approach in civil cases. Department of Social Services v. Stein, 328 Md. 1, 612 A.2d 880 (1992).

In Zaal itself, the Court of Appeals held that "controlled access by counsel to the records" was required, and remanded for consideration of whether the third or the fourth alternative outlined above was the more appropriate. $326 \mathrm{Md}$. at 88.

In Samie v. State, $181 \mathrm{Md}$. App. 59, 955 A.2d 794 (2008), the court addressed in camera review of confidential juvenile records that might contain inconsistent statements of a key witness the defense would call as a hostile witness. In a significant opinion by Judge Meredith, the Court of Special Appeals held that a defendant's confrontation right was implicated when a juvenile and his parents had been involved in an altercation with the defendant that led to the charges against the defendant. The juvenile had agreed to a "statement of facts" that was used in his juvenile proceedings relating to the melée. The defense sought access to the statement of facts for potential use as impeachment evidence when it called the juvenile as a hostile witness. The applicable statute permits disclosure of confidential juvenile matters "upon good cause 
shown," and the trial court was held to have committed reversible error in not examining the material in camera and deciding whether that standard was met.

\section{Exclusion of Public from the Hearing}

Md. Code Ann., Cts. \& Jud. Proc. § 3-810(b)(2) provides: “The [juvenile] court shall exclude the general public from a hearing where the proceedings involve discussion of confidential information from the child abuse and neglect report and record, or any information obtained from the child welfare agency concerning a child or family who is receiving Title IV-B child welfare services or Title IV-E foster care of adoption assistance."

The Court of Appeals, after reviewing the legislative history of the statute, concluded that its purpose is "to prevent disclosure of confidential information concerning allegations and evidence of abuse that would impair the treatment and rehabilitation of the children and parents or guardians involved" and that, therefore, a juvenile court judge had not erred in permitting social workers "who already knew of information concerning the child abuse in issue to remain during the hearing." In re Ashley E., 387 Md. 260, 874 A.2d 998 (2005).

\section{3. "Privileged" Matters}

In Goldsmith v. State, 337 Md. 112, 127-28, 651 A.2d 877 (1995), which concerned psychiatrist-patient records, the majority of the Court of Appeals distinguished between "privileged" matters and merely "confidential" matters and held that "in order to abrogate a privilege such as to require disclosure at trial of privileged records, a defendant must establish a reasonable likelihood that the privileged records contain exculpatory information necessary for a proper defense." A "speculative assertion that the records might be relevant for impeachment" is insufficient. Id. at $133,135$.

\section{Competency of Children to Testify}

If the judge, in his or her discretion, determines - based on interviewing the child - that a young child has sufficient ability to observe, remember, and communicate the relevant facts and feels the duty to tell the truth, the judge will permit a child's testimony.

Failure to conduct such an examination of the child, and ruling instead that, because of the child's age, he or she is incompetent to testify as a matter of law, has been held to be reversible error.

See generally 6 Maryland Evidence $§$ 601:3. See also Md. Code Ann., Cts. \& Jud. Proc. $\S 9-103$ (in a child abuse case, the alleged child victim may not be precluded from testifying because of "age."). 


\section{Erroneous Admission of Evidence in CINA Proceedings Is Less Crucial than Erroneous Exclusion}

In reviewing nonjury trials, appellate courts will consider only whether the properly admitted evidence, viewed in the light most favorable to the appellee, provides sufficient support for the trial court's decision. They will assume that the judge ignored all improper evidence, unless the judge's reliance on it is clear from his or her opinion. See In re Beverly B., $72 \mathrm{Md}$. App. 433, 443, 530 A.2d 766, 771 (1987) (trial court made it clear that it did not rely on hearsay evidence).

\section{Opinion Evidence: Md. Rules 5-701-5-706}

See In re Yve S., 373 Md. 551, 819 A.2d 1030 (2003) (reversible error to admit and rely on social worker's lay diagnosis that mother was becoming "manic," which contradicted testimony of mother's psychiatrist).

\section{Hearsay Exceptions of Particular Interest regarding Child's Statements: If the Child Testifies and Is Subject to Cross-Examination Concerning the Statement}

A. Md. Rule 5-802.1(d): "prompt complaint of sexually assaultive behavior to which the declarant was subjected," when the complaint is "consistent with the declarant's testimony ..." at the trial or hearing.

See Gaerian v. State, 159 Md. App. 527, 860 A.2d 396 (2004) (child's statements to a peer, within one month of most recent of allegedly years-long sexual abuse, qualified as "prompt"); Nelson v. State, 137 Md. App. 402, 409-10, 414-19, 768 A.2d 738 (2001); Harmony v. State, 88 Md. App. 306, 321, 594 A.2d 1182, 1189 (1991) (evidence of fourteen-year-old girl's telephone call to her sister, relating sexual abuse by their uncle, that had occurred that evening, was properly admitted as either an "excited utterance or a timely complaint of a sexual attack") (alternate holding); 6A MARYLAND EVIDENCE § 801(3):2.

B. Md. Rule 5-802.1(a): Written or Recorded Prior Inconsistent Statements, or Prior Testimony Inconsistent with Testimony Today

See Nance v. State, 331 Md. 549, 629 A.2d 633 (1993); 6A MARYLAND EviDENCE § 801(1):1.

C. Md. Rule 5-802.1(b): The Declarant's Prior Consistent Statements Made Before the Alleged Impeaching Fact Tending to Show "Fabrication, or Improper Influence or Motive"

See Tome v. United States, 513 U.S. 150 (1995) (child abuse case); Holmes v. State, 350 Md. 412, 712 A.2d 554 (1998); 6A MARYLAND EVIDENCE § 801(2):1. 


\section{Hearsay Exceptions that Apply Regardless Whether the Child-Declarant Testifies or Not (in a non-criminal proceeding)}

\section{A. Is Competency of a Child to Testify at Time of Trial Required?}

The child declarant need not be shown to have been competent to testify, at least to permit the child's "excited or spontaneous utterances or [statements offered pursuant to] statutory admissibility [e.g., 'tender years']," Stoddard v. State, 389 Md. 681, 715-16, 742-44, 887 A.2d 564 (2005) (Wilner, J., concurring, joined by Battaglia and Greene, JJ.); Jackson v. State, $31 \mathrm{Md}$. App. 332, 338-39, 356 A.2d 299 (1976). See Idaho v. Wright, 497 U.S. 805, 823, 825 (1990); 6A MARYLAND EVIDENCE $§ 803: 1$.

\section{B. $\quad$ Md. Rule 5-803(a): Statement of a Party-Opponent}

Who is the party-opponent in a CINA case? The child and the child's parent or guardian are parties. A child's statements could be offered against the child as an admission of a party opponent, but not against his or her parent (unless the parent authorized or adopted the statements). In re Michael G., 107 Md. App. 257, 667 A.2d 956 (1998). See generally 6A MARYLAND EVIDENCE $§ \S 801(4): 1$ et seq.

\section{C. $\quad$ Md. Rule 5-803(b)(1): Present Sense Impression}

Foundation:

(1) Statement "describes or explains an event or condition" and

(2) Was "made while the declarant was perceiving [it], or immediately thereafter"

E.g., “There's nobody here but me.” "Mama's asleep and she won’t wake up.”

See, e.g., Booth v. State, 306 Md. 313, 508 A.2d 976 (1986) (declarant's unexcited statement over telephone that a "girl named Brenda" was in his apartment and was "talking to 'some guy' behind the door”). See generally 6A MARYLAND EVIDENCE § 803(1):1.

\section{Md. Rule 5-803(b)(2): Excited Utterances}

Foundation:

(1) A startling event occurred;

(2) At the time of the statement, the declarant remained so under the stress of the startling event as to preclude reflection (and thus fabrication); and

(3) The statement relates to the startling event. 
E.g., "Help! Mama fell down and she's hurt!" "Daddy got mad and threw me down the steps!" "The house is on fire!"

Compare, e.g., Harmony v. State, 88 Md. App. 306, 317-21, 594 A.2d 1182 (1991) (no abuse of discretion in admission of evidence as excited utterance, when foundational evidence supported finding that the statement - a telephone call by a crying fourteen-year-old girl to her sister, relating sexual abuse by their uncle that had occurred that evening - was uttered spontaneously, so that she was incapable of "forethought or deliberate design"); Jackson v. State, 31 Md. App. 332, 356 A.2d 299 (1976) (statements of a four-year-and-three-month-old victim, who was crying, of sexual assault to her mother and sister, in response to question what was wrong, were properly admitted); Moore v. State, 26 Md. App. 556, 559-67, 338 A.2d 344 (1975) (no abuse of discretion to admit statement by three-and-one-half-year-old child that " Daddy was mad, Daddy did it,' " made to physician in response to question, within hours after alleged beating which inflicted massive injuries); and Sears v. State, 9 Md. App. 375, 383-84, 264 A.2d 485 (1970) (police officer's testimony to statements, within half hour after assault, made by 11-year-old assault victim after she had fled to police station was properly admitted) with Mouzone v. State, 294 Md. 692, 698, 701, 452 A.2d 661 (1982) (stressing "the importance of examining the circumstances in toto to determine whether the statement was the result of reasoning and reflection or a spontaneous response to the exciting event"; there, declarant's statement to police officer, three hours after witnessing crime and suffering epileptic seizure, made after she had begun to calm down, when she was interviewed for two hours, and she read and signed statement, was held to be "the product of thoughtful consideration and thus outside the excited utterance exception"). See generally 6A MARYLAND EVIDENCE $§ 803(2): 1$.

\section{E. $\quad$ Md. Rule 5-803(b)(3): Statements of the Declarant's Then Existing Physical Condition, No Matter to Whom Made}

E.g., "My tummy hurts."

See, e.g., Fisher v. State, 128 Md. App. 79, 143, 736 A.2d 1125 (1999) (child abuse victim's statements), aff'd in part, vacated in part, 367 Md. 218, 786 A.2d 706 (2001). See generally 6A MARYLAND EVIDENCE $§$ 803(3):2.

\section{F. $\quad$ Md. Rule 5-803(b)(3): Statements of the Declarant's Then Existing State of Mind or Emotion}

The statement cannot be offered to prove something that happened before the statement was made. E.g., "I hate Auntie because she beats me" (admissible to prove emotion but not what caused it so last part must be redacted, even if child's state of mind is relevant). 
See, e.g., Nash v. State, 69 Md. App. 681, 690-91, 519 A.2d 769 (1987) (no abuse of discretion in admitting social worker's testimony that child victim expressed surprise and fear that witness knew of abuse). See generally 6A MARYLAND EVIDENCE § 803(3):1.

\section{G. $\quad$ Md. Rule 5-803(b)(4): Statements Made When the Declarant Is Seeking Medical Treatment (or Diagnosis with a View to Treatment, If Necessary)}

Foundation:

(1) Declarant was seeking medical treatment or medical diagnosis in contemplation of treatment (for oneself or loved one)

See Hutton v. State, 339 Md. 480, 507, 510-11, 663 A.2d 1289 (1995) (Rodowsky, J., concurring, joined by Murphy, C.J.) (Md. Rule 5-803(b)(4) extends to mental health care provider).

Statements to nontreating physicians - employed with a view to litigation - are not covered by the rule. E.g., Low v. State, 119 Md. App. 413, 705 A.2d 67 (1998) (examination by physician who worked for the Montgomery County Department of Health and Human Services, after a social worker's referral).

(2) Speaking to someone declarant thought could provide or obtain such treatment.

(3) Describing past or present symptoms, pain, sensation, medical history, inception or general character of the cause or external sources.

(4) Only that part of the information that is "reasonably pertinent to treatment or diagnosis in contemplation of treatment."

(5) Child declarant must understand treatment is at stake, so that accuracy of statement will affect treatment.

This requirement was held not to have been met in, e.g., Cassidy v. State, $74 \mathrm{Md}$. App. 1, 33, 536 A.2d 666 (1988).

(6) Identity of a perpetrator is admissible under this exception only if medical professional testifies that identity is relevant to treatment or diagnosis within Rule 8-303(b)(4) (and declarant must understand this fact).

E.g., "Somebody threw me down the stairs." 
Compare, e.g., "Daddy did it to me but he does it more to my sister." "Daddy gets drunk and thinks I'm his wife."

E.g., Griner v. State, 168 Md. App. 714, 745-46, 899 A.2d 189 (2006); Webster v. State, 151 Md. App. 527, 536, 827 A.2d 910 (2003) (examination by SAFE nurse); In re Rachel T., 77 Md. App. 20, 36, 549 A.2d 27 (1988) (given five-year-old Rachel's vaginal bleeding and abnormally dilated hymen, "it was possible that [she] had been exposed to venereal disease, and may have required antibiotics" and "[A] scertaining the identity of the abuser was also important in the instant case because effective treatment might have required Rachel's removal from the home."); Cassidy v. State, $74 \mathrm{Md}$. App. at 34 n.14 ("When there is a danger that an assault victim may have contracted a communicable disease, [however], the identity of the assailant may take on significant medical pertinence.").

See Bentley v. Carroll, 355 Md. 312, 734 A.2d 697 (1999) (a patient properly stated a medical malpractice claim against her treating physicians for failing to prevent continual, long-term child sexual abuse by members of her household).

The Court of Appeals held in State v. Coates, 405 Md. 131, 950 A.2d 114 (2008), that statements of a seven-year-old to a SAFE pediatric nurse practitioner, regarding sexual abuse occurring over a year earlier, were erroneously admitted by the trial court as substantive evidence, under Rule 5-803(b)(4). The appellate court reversed the resulting conviction, holding that there was inadequate evidence to support a finding that the child, who was suffering no physical symptoms at the time of the interview, understood that there was a medical purpose for the examination. Although the nurse ordered testing for HIV, there was "no indication that [the child] had any understanding ..., that she was at continued risk of developing a latent sexually transmitted disease or HIV." The fact that she was diagnosed with genital herpes four months later did not relate back to this interview. $405 \mathrm{Md}$. at $145 \mathrm{n} .11$. The child's statement regarding the identity of her alleged abuser was inadmissible under this exception "because the identity of the perpetrator is not ordinarily of strict medical importance, and Jazmyne T. was not aware that her statement was relevant to medical treatment or diagnosis. Id. at 134.

See generally 6A MARYLAND EVIDENCE $§ 803(4): 1$.

H. Md. Code Ann., Crim. Pro. $\$ 11-304:$ The “Tender Years" Exception (applicable to CINA cases)

Foundation:

(1) Other hearsay exceptions are inapplicable and the proponent of the evidence must give pretrial notice of intent to use this exception. 

age.

See Nixon v. State, 140 Md. App. 170, 178-79, 185, 780 A.2d 344 (2001) (statute was inapplicable when victim was sixteen years old, although she was mentally retarded and had a mental age of approximately six years and two months).

The child abuse need not be sexual in nature. Cole v. State, 83 Md. App. 279, 304-05, 574 A.2d 326 (1990).

Statement was made to a physician, psychologist, nurse, social worker, or teacher "acting lawfully in the course of [his or her] profession."

See Lawson v. State, 389 Md. 570, 581-85, 886 A.2d 876 (2005) (social worker was acting in the course of her profession when she interviewed alleged child abuse victim as result of notification by police).

(4) Trial judge finds statement to be reliable, considering all the criteria in the statute.

(5) The confrontation clause does not apply in non-criminal proceedings, so the child need not (but may) testify at the hearing. If the child does not testify, the child's out-of-court statement will be admissible only if there is corroborative evidence that the alleged abuser had the opportunity to commit the alleged offense.

See generally 6A MARYLAND EVIDENCE § 803(27):1.

\section{I. $\quad$ Rule 5-803(b)(8): Public (Government) Records}

If a government agency or employee is the author, the public records exception of $\mathrm{Md}$. Rule 5-803(b)(8) applies, not the business records exception of Md. 5-803(b)(6). See generally 6A MARYLAND EVIDENCE $§ 803(8): 1$.

If the hearsay statement of a person outside the government (or business) is included, another hearsay exception (or nonhearsay purpose) must be applicable, or else that part must be redacted. Md. Rule 5-805. See, e.g., Hall v. University of Maryland Medical Sys. Corp., 398 Md. 67, 919 A.2d 1177 (2007). See generally 6A MARYLAND EvIDENCE $§ 805: 1$. When such a problem of "double hearsay" or "multiple hearsay" arises, if the more recent out-of-court statement cannot be admitted, there is an insuperable barrier. If it can be admitted, any "double hearsay" within it must be excluded, unless it also falls within hearsay exception or is admitted for a relevant nonhearsay purpose. See, e.g., Borchardt v. State, 367 Md. 91, 130-31 (2001). 
The government declarant's hearsay statement may qualify under:

(1) Md. Rule 5-803(b)(8)(A): government worker's own activities; or

(2) Md. Rule 5-803(b)(8)(B): government worker's report of others' activities, as to which government worker has duty to report; or

(3) Md. Rule 5-803(b)(8)(C): factual findings of government worker as a result of investigation made pursuant to legal authority.

E.g., CASA's written reports to court re: background information, contacts, and recommendations regarding placement (Md. Code Ann., Cts. \& Jud. Proc. § 3-830;

Administrative Office of Courts CASA Rules and Guidelines at 4). See In re Billy W., $387 \mathrm{Md}$. at 434-46; In re Wanda B., 69 Md. App. 105, 516 A.2d 615 (1986) (court-ordered psychiatric report was admissible in CINA proceeding).

Inadmissible if shown to have relied on unreliable sources (burden on opponent who seeks exclusion).

See also Md. Code Ann., Fam. Law § 5-1029(f) (agency’s investigative report admissible in independent adoption case in which parental consent is withheld).

(4) Authentication: Certified Copies

Md. Rules 5-902(a) (method of certification) and 5-902(a)(4) (public records); Md. Code Ann., Cts. \& Jud. Proc. § 10-204 (from federal, any state, U.S. territory, political subdivision, or agency thereof). See also, as to non-certified copies, Md. Rule 5-901(b)(7).

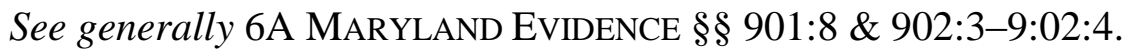

\section{B. $\quad$ Md. Rule 5-803(b)(6): Business Records}

Foundation:

(1) A writing;

(2) Foundation laid by custodian or other qualified witness or certification [or circumstantial evidence-] that

(3) Made and kept in course of a "business" activity;

(4) Regular practice of that "business" to make the writing; and 
(5) It was made at or near the time of the act, etc., recorded;

(6) By (or from information from) a person with first-hand knowledge.

Then not excluded by the hearsay rule, UNLESS the source, method, or circumstances indicate lack of trustworthiness (burden is on opponent to show this):

(1) The Johnson v. Lutz doctrine: If the out-of-court statement of someone not in the business is related in the business record, another hearsay exception (or a nonhearsay purpose) for that statement must be found in order to have that portion admitted. See Md. Rule 5-805.

(2) The Palmer v. Hoffman doctrine: A self-serving out-of-court statement made in anticipation of litigation, e.g., an accident report in which a truck driver tells her employer she was obeying all rules of the road, is unreliable and, therefore, inadmissible as a business record.

See generally 6A MARYLAND EVIDENCE $§ 803(6): 1$.

The business records hearsay exception is:

1. Applied to hospital records, for example.

E.g., In re Colin R., 63 Md. App. 684, 691-94, 493 A.2d 1083 (1985).

2. Assailable by opponent if business relied on unreliable sources.

E.g., Moon v. State, 300 Md. 354, 371-72, 478 A.2d 695 (1984) (hospital records of blood alcohol tests made 3 days after blood was drawn).

Other relevant points:

1. Need not call custodian or other witness to lay foundation: may lay foundation through certificate according to form set forth in Md. Rule 5-902(b)(1)-(2) (advance notice of at least 10 days required, see Md. Rule 5-902(b)(1)).

2. Multiple hearsay problem, Md. Rule 805.

3. Subpoena

See Newcomb v. Owens, 54 Md. App. 597, 604-05, 459 A.2d 1130 (1983). 


\section{Photographs: Authentication}

Foundation: need not be the photographer, just a witness who saw the real thing and can testify photo is a "fair and accurate" representation of it.

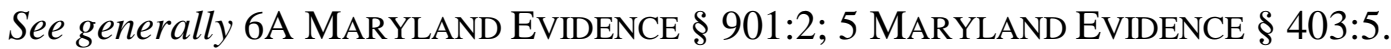

\section{Character Evidence to Prove Abuse or Neglect}

See generally 5 MARYLAND EVIDENCE $§ \S ~ 404: 1$ et seq.

\section{A. $\quad$ Finding Required}

When a court has reasonable grounds to believe that neglect or abuse of any child has occurred, custody or visitation must be denied, except for supervised visitation, unless the court makes a specific finding that there is no likelihood of further abuse or neglect. In re Billy W., 387 Md. at 447, 450-51, $455-57$ (citing Md. Code Ann., Fam. L. § 9-101); In re Yve S., 373 Md. 551, 566-67, 819 A.2d 1030 (2003); In re Adoption No. 12612, 353 Md. 209 (1999).

\section{B. Exceptions to Propensity Rule of General Exclusion}

\section{The "Vogel" Exception}

Maryland's case law permits proof of prior sexual acts with the same alleged abuser and the same victim. E.g., Acuna v. State, 332 Md. 65, 72-76, 629 A.2d 1233 (1993) (evidence properly admitted); Vogel v. State, 315 Md. 458, 554 A.2d 1231 (1989). See Thompson v. State, 181 Md. App. 74, 955 A.2d 802 (2008), cert. granted, 406 Md. 744, 962 A.2d 371 (2008)

(victim's testimony to uncharged sexual abuse of her by defendant, including one instance when he was also a juvenile, was properly admitted; trial court properly found that evidence was clear and convincing and did not abuse its discretion in not excluding it under Md. Rule 5-403, where victim's credibility was central to case and jury benefitted from understanding context of her allegations).

\section{Domestic Spousal and Child Abuse}

In Coburn v. Coburn, 342 Md. 244, 258, 674 A.2d 951 (1996), the Court of Appeals affirmed the trial court's admission, in a hearing at which a spouse might obtain a protective order pursuant to the domestic violence statute, of the defendant's alleged prior abusive acts against the spouse. The court stressed the preventive nature of the proceeding and stated that the evidence was not offered to prove that the defendant currently had acted in conformity with past acts: 
The more abuse that occurred in the past, the higher the likelihood that future acts of abuse will occur and thus, the need for greater protective measures. . . .

Evidence of prior incidents of abuse is therefore highly relevant both in assessing whether or not to issue a protective order and in determining what type of remedies are appropriate under the circumstances.

These proceedings seem analogous to shelter care proceedings in that respect. $C f$. Md. Code Ann., Fam. Law § 9-101.1 (as to whether to deny child custody or visitation rights to a parent, the court may consider evidence of abuse by a party against: "(1) the other parent of the party's child; (2) the party's spouse; or (3) any child residing within the party's household, including a child other than the child who is the subject of the custody or visitation proceeding.").

\section{3. “MIMIC, ” Especially Proof of Other Specific Instances to Prove Absence of Mistake or Accident.}

See Wilson v. State, 136 Md. App. 27, 85-90, 764 A.2d 284 (2000), rev'd and remanded, 370 Md. 191, 216-17, 803 A.2d 1034 (2002) (in trial for murder of accused's infant child, on whose life he had purchased insurance, evidence of his having purchased and recovered on life insurance for two other infants who died under highly similar circumstances, when he was near them, was properly admitted to show his motive, his intent, his identity as the perpetrator, and the lack of accidental death) (this issue not addressed by Court of Appeals, as expert testimony on remand would affect whether other death was properly viewed as a prior bad act); Dyson $v$. State, 6 Md. App. 453, 456, 251 A.2d 606 (1969) (in prosecution for murder and child abuse, photographs showing prior abuse of the victim admissible as showing intent or common scheme; defendant testified that injuries were accidental). But see Boyd v. State, 399 Md. 457, 924 A.2d 1112 (2007) (in defendant's trial for violation of a protective order, reversible error to admit other acts evidence on theory that it was relevant to defendant's absence of mistake, when he never asserted that he acted mistakenly). See generally 5 MARYLAND EVIDENCE $\S \S$ 404:5-404:13.

\section{Impeachment}

\section{A. Md. Rule 5-608(b): Impeachment by Prior Bad Acts}

See generally 6 MARYLAND EVIDENCE $§$ 608:1.

\section{When the Person to Be Impeached Does Not Testify at the Hearing}

When a witness does not testify at trial, but his or her out-of-court statement is admitted as substantive evidence, Md. Rule 5-806 permits impeachment of that declarant. But how does that square with Md. Rule 5-608(b)'s exclusion of extrinsic evidence of a witness's prior bad acts that did not result in conviction but are probative of a character for untruthfulness? The Court of Appeals held in Taylor v. State, 407 Md. 137, 963 A.2d 197 (2009), that a trial court committed error (albeit harmless under the facts of the case) when it precluded impeachment of the 
non-testifying, third degree sexual assault victim with extrinsic evidence-testimony of other witnesses-that the young victim had lied to others about his prior sexual experience. The appellate court held that the defense should have been permitted to ask only the same questions it could have properly asked the victim, had he testified. Further extrinsic proof of the misconduct was precluded, just as it would have been, had the victim testified. See generally 6A MARYLAND EVIDENCE $§$ 806:1 (impeachment of a nontestifying hearsay declarant).

\section{DSS Findings}

Is a DSS conclusion that an allegation was "unfounded" evidence that it was false? See Cookson v. Schwarz, 556 F.3d 647, 652-55 (7th Cir. 2000) (state court did not act contrary to clearly established federal law in excluding, in child sexual abuse case, questioning of victim about her charge-found by social services, on appeal, to be unfounded-that another person had also sexually abused her; "a DCFS finding that an allegation was 'unfounded' does not, by itself establish that the allegation was false") (footnote omitted).

\section{B. $\quad$ Md. Rule 5-613: Impeachment by Prior Inconsistent Statements}

See generally 6 MARYLAND EVIDENCE $§$ 613:1; Note, Legal and Scientific Issues Surrounding Victim Recantation in Child Sexual Abuse Cases, 24 GA. ST. U. L. REV. 779 (2008). Compare 6A MARYLAND EVIDENCE $\S 801(1)$ : 1 (admissibility of written or recorded inconsistent statements as substantive evidence, when declarant testifies at the hearing).

\section{Judicial Notice, Md. Rule 5-201}

E.g., of other proceedings in same court, e.g., earlier DSS referrals (but not of truth of earlier testimony nor of early record when adjudicative hearing is de novo). See generally 5 MARYLAND EVIDENCE $\S \S 201: 1-201: 5$.

\section{Burden of Proof}

See In re Nicole B., 410 Md. 33, 976 A.2d 1039 (2009) (declining to decide whether the federal requirement under 25 U.S.C. $§ 1912$ (d) that a party seeking to terminate parental rights to, or put in foster care, a Native American child must have made "active efforts" of remediation and rehabilitation to keep the family together, is the same as the state standard under Md. Code Ann., Fam. L. § 5-525(d) to make "reasonable efforts . . to preserve and reunify families"; holding that evidence showed that DHHS did make such "active efforts" over the course of 15 months), rev'g 175 Md. App. 450, 927 A.2d 1194 (2007). Judge Raker (who is now retired), joined by Chief Judge Bell, dissented; Judge Adkins (who is now on the Court of Appeals) wrote the opinion for the CSA. Compare, as to failure to have made "reasonable efforts," In re James G., 178 Md. App. 543, 943 A.2d 53 (2008). 